\title{
Laguntzadun enpleguaren bidez autismo espektroaren nahastea duten pertsonen laneratzea enplegu ordinarioan. Hiru esperientzien azterketa
}

\author{
Maider Escurza Zubiaur \\ Euskal Herriko Unibertsitatea (UPV/EHU) \\ <kidis18@hotmail.com>
}

\section{Monike Gezuraga Amundarain \\ Euskal Herriko Unibertsitatea (UPV/EHU)}

Ondorengo ikerketa kualitatiboaren xedea autismo espektroaren nahastea duten pertsonak laguntzadun enpleguaren bidez enplegu ordinarioan nola txertatzen diren miatzea izan da. Horretarako, elkarrizketa sakonak eta erdi-egituratuak garatuz, nahaste hau duten hiru langile eta prozesu horretan lagundu duten senide eta profesional desberdinen diskurtsoa aztertu da, hauek guztiek bizi izandako hiru esperientziak aintzat hartuz: enplegu ordinarioa, laguntzadun enplegua eta zentro okupazionala. Ikerketaren ildo azpimarragarriek desgaitasuna duten pertsonak laguntza egokia izanez enplegu ordinario batean lan egiteko kapaz direla erakutsi dute. Gainera, etorkizunari begira pertsona hauen egoera lan esparruan normalizatzeko premia azaleratu da, konpromiso horretan herritar guztiek parte hartuz. Azkenik, lan prestatzailea alde guztien arteko bitartekotzat zein prozesuan zehar pertsona bideratzen duen etengabeko orientatzailetzat hartu beharra dago.

\section{GAKO-HITZAK:}

Autismo espektroaren nahastea, enplegu ordinarioa, laguntzadun enplegua, gizarteratzea, lan prestatzailea.
El objetivo de la siguiente investigación cualitativa ha sido examinar cómo se incorporan las personas con trastorno del espectro autista en el empleo ordinario a través del empleo con apoyo. Para ello, mediante entrevistas en profundidad y semiestructuradas se ha analizado el discurso de tres trabajadores/as con este trastorno y de diferentes familiares y profesionales que han ayudado en ese proceso, teniendo en cuenta las tres experiencias vividas por los/as tres trabajadores/as: empleo ordinario, empleo con apoyo y centro ocupacional. La investigación muestra que, con ayuda adecuada, las personas con discapacidad son capaces de trabajar en un empleo ordinario. Además, de cara al futuro ha quedado de manifiesto la necesidad de que la situación de estas personas en el ámbito laboral se normalice, proceso en el que ha de participar la ciudanía en su conjunto. Por último, es necesario considerar al preparador/a laboral como mediador/a entre todas las partes y como orientador/a que guía a la persona durante el proceso.

\section{Palabras Clave:}

Trastorno del espectro autista, empleo ordinario, empleo con apoyo, integración social, preparador/a laboral. 


\section{Sarrera}

Gaur egungo gizartea lan esparruan zailtasun handiko aldia pairatzen ari dela ukaezina da. Egoera hau, tamalez, are zailagoa suerta daiteke desgaitasunen bat duten pertsonentzako, autismo espektroaren nahastea (aurrerantzean AEN) dutenentzako kasu, nahaste hau duten langileak ohiko enpresetan aurkitzea ez baita ataza erraza. Hala ere, desgaitasuna duten pertsonen enplegu ordinarioa bultzatzen duten ekimenak hainbat dira, laguntzadun enplegua barne. Programa hau lan giroetan desgaitasuna duten pertsonen jarduera normalizatzen saiatzen da, eskubide osoko herritar bezala (Jordán de Urríes, Verdugo eta Vicent, 2005). Baliabide honen baliagarritasuna aztertzeko, ikerketa kualitatibo bat aurrera eraman da, esparruan murgilduta dauden hiru kasuen inguruan elkarrizketak ${ }^{1}$ burutuz. Ondoren, baturiko datuen ardatz garrantzitsuenak hartuz analisia egin da eta emaitzak lortu dira. Amaitzeko, etorkizunerako lagungarriak izango diren ondorioak atera dira.

\section{Autismoa}

\subsection{Definizioa}

Autismoa haur batzuei, jaiotzetik zein lehenengo haurtzarotik, eragiten dien nahaste bat da. Honek, maila desberdinetan, harreman sozial edo komunikazio arruntak eratzeko eta garatzeko ez gai egiten die. Ondorioz, haurra gizakiaren harremanetik isolatua eta errepikakorrak eta obsesiboak diren ekintza eta interes mundu batean murgildua izan daiteke (Baron-Cohen eta Bolton, 2003). Hortaz:

Es autista aquella persona para la cual las otras personas resultan opacas e impredictibles; aquella persona que vive como ausentes -mentalmente ausentes- a las personas presentes, y que por todo ello se siente incompetente para regular y controlar su conducta por medio de la comunicación (Rivière, 2001: 16).

Haur hauek, azken finean, askotan gainerakoekin harreman afektiboa eratzeko berezko ezgaitasunarekin heldu dira mundura (Kanner, 1993). Gainera, kontua ez da soilik maiz autismoa duten pertsonek beren harreman pertsonaletan hutsune harrigarriak dituztela, baizik eta zenbaitetan ohiz kanpoko moduan pentsatzen eta hitz egiten dute, adimen urritasun orokorrak aurkezten dituzte, eta ekintza estereotipatuak egin edo kezka oso bereziak izan ohi dituzte (Hobson, 1995). Ikusten denez, sozializazio, komunikazio eta irudimen arazoak nahikoak eta beharrezkoak dira autismoaren zati handia azaltzeko (Wing, 1988).

Modu honetan, autismoa duten pertsona batzuek, batetik, harreman sozialak ezartzeko zailtasuna

${ }^{1}$ 2015eko ekainean eta uztailean gauzatuak. erakusten dute. Hau beste pertsonekin elkarri eragiteko arazoetan, emozioak espresatzeko eta gainerakoei erantzuteko zailtasunean eta seinale sozialen balorazio desegokian eta erabilera urrian azaltzen da. Bestetik, noizean noiz mintzamenaren agerpenean eta garapenean atzerapen bat dago. Erdiak, gutxi gorabehera, ez du modu espontaneoan ahozko lengoaiarik garatzen. Ahozko lengoaia eskuratzen duten hainbatek mintzamen monotonoa, intonaziorik gabekoa eta errepikakorra aurkeztu ohi dute, ekolalia anitzekin, ni eta zu izenordainen arteko nahasketarekin eta enpatia adierazten duten portaeretan zailtasunekin. Beren ulermen mailan ere eragina dauka eta batzuek termino abstraktuak ulertzeko zailtasun handiak aurkezten dituzte (Cuadrado eta Valiente, 2005).

Gainera, baten batzuk egiten dituzten ekintzetan zurruntasuna azaltzen dute, aldaketen aurrean antsietate handia adierazten dute eta jokoetan eta gaietan duten interesa mugatua da. Esandakoaz gain, noizik behin objektu arraroei lotura eta hauen ezohiko erabilera erakusten dute eta, gradu batean edo bestean, prozesu sinbolikoetan gabezia aurkezten dute, irudimenezko ekintzetarako beharrezkoa dena (Cuadrado eta Valiente, 2005).

\subsection{Bilakaera historikoa}

la erabateko segurtasunarekin autismoa beti egon da, izan ere kultura gehienetan gizabanako oso sinpleei buruz kondairak aurki daitezke, portaera oso arraroak eta sen onaren gabezi deigarria dutenak (Happé, 2007). Horrela, haur arraroak, misteriotsuak eta enigmatikoak historiaren bidez gure kulturaren parte izan dira. Horietako batzuk haur basati bezala ezagunak ziren, otseme edo beste animali basatiengatik haziak (Coleman eta Gillberg, 1989). Esaterako, Lorna Wing-ek Victor-en kasuan, Aveyron-go haur basatiaren kasuan alegia, nahaste autista bat dagoela argudiatzen du (Wing, 1997).

Suitzako Bleuler psikiatrak 'autista' hitza lehenengo aldiz erabili zuen (Baron-Cohen, 2010), gizartetik urruntzen eta barneko mundu batean sartzen zen eskizofrenikoaren portaera deskribatzeko asmoz (Alonso Peña, 2009). Hitz hau Greziako autos hitzetik dator eta ‘bere buruarekin' esan nahi du (BaronCohen, 2010). Psikiatra honek autista hitza 1911n sortu zuen, hala ere sindrome autistaren lehenengo definizioa bi psikiatren gain azaldu zen; Leo Kanner eta Hans Asperger (García-Villamisar, 2006b).

Leo Kanner-ek, Austrian jaiotako psikiatrak, autismorako bere ikasketen zati handia Amerikako Estatu Batuan garatu zuen eta honen deskribapen zientifikoari esker, historiako lehena, autismoa identitate bezala onartzen hasi zen (Martos eta Burgos, 2013). Modu honetan, autismo hitzak egun duen esanahia Leo Kanner-i zor zaio, honek 1943an egungo autismoaren oinarrizko artikulua den "Autistic disturbances of affective contact" argitaratu baitzuen, bertan bere arreta deitu zuten 11 haurrei 
egindako behaketak bildu ostean (Artigas-Pallarès eta Paula, 2012). Gainera, artikuluan behaturiko haur guztiek partekatzen zituzten ezaugarriak ere nabarmendu zituen, besteak beste, sekulako bakardade autista, ingurunea aldaketarik gabe mantentzeko nahia, oroimen bikaina, estimuluei hipersentiberatasuna eta ekintza espontaneoaren aldaeran mugak (Happé, 2007). Azken finean, beren hasierako bizitzatik izugarrizko bakardadea eta monotonia mantentzeko desira obsesiboa ezaugarrietan bat etortzen zirela egiaztatu zuen (Coleman eta Gillberg, 1989).

Hans Asperger-ek, Austrian ere jaiotako medikuak, 1944an haurtzaroan 'psikopatia autista'-ri buruzko hitzaldi bat argitaratu zuen (Happé, 2007). Bertan Asperger-ek berariazko ezaugarriak aurkezten zituen haur mota desberdin bat ikertzen jardun zuen (Baron-Cohen, 2010). Honek burututako jatorrizko ikerketaren zabaltzea urria eta mugatua izan zen; agian lana alemanez argitaratu zelako eta Alemania Bigarren Mundu Gerran murgilduta zegoelako (Martín Borreguero, 2004). Egoera hau 1981ean aldatu zen, Lorna Wing-ek ingelesera bere lanen itzulpena egin ondoren (Artigas-Pallarès eta Paula, 2012). Diagnostikoaren irizpideei oniritzia ematen dieten nazioarteko batzordeek 1994an azpitalde hau onartu zuten (Baron-Cohen, 2010).

Kanner-en ideia gehienek gaur egun indarrean jarraitzen dute eta, Hans Asperger-en lanarekin batera, egungo ikusmoldearen oinarriak funtsatzen lagundu dute (Martos eta Burgos, 2013). Hala ere, prozesu hori ez da erraza izan; 5oeko eta 6oko hamarkadetan, nahasketa terminologiko baten erdian, autismoa eskizofrenia eratzat hartua zen, haurren autismoa, haurren psikosia edo haurren eskizofrenia bezalako etiketen erabileraren bidez. Haatik, 6oko hamarkadaren bukaeran eta 7oekoaren hasieran aditu batzuk autismoaren ikuspegi hau zalantzan jartzen hasi eta ondorengo bi hamarkadetan, ikuspegi kognitibo eta neuropsikologiko batetik, autismoan oinarrizko gabeziaren izaerari buruz aztertzen duten ikerketa ildoak azaldu ziren (Murillo, 2012).

\subsection{Autismo espektroaren nahastea}

Kanner-ek autismoari buruz egindako deskribapen originala denboraren poderioz aldatzen joan da (Happé, 2007). Horrela, 6oko hamarkadaren amaieratik ez da bakarrik fintasuna areagotu autismoaren definizioan, baizik eta espektroaren nahastea kontzepturantz ere zabaldu da. 1979an Lorna Wing-ek eta Judith Gould-ek egindako ikerketa bat kontzeptu honen oinarrian dago (Martos eta Burgos, 2013).

Bertan Kanner-ek deskribatutako ohiko ereduarekin bat zetozen pazienteak identifikatu zituzten. Halaber, Kanner-en profilarekin bat etorri gabe, maila batean edo bestean interakzio sozialean, komunikazioan eta irudimenean arazoen hirukoa erakusten zuten pazienteek ere detektatu zituzten, jokaera patroi zurrunei eta errepikakorrei lotua (Artigas-Pallarès eta Paula, 2012). Gainera, adimen maila edozein izanda ere hirukoa identifikatua izan daitekeela azpimarratzen zuten, eta beste arazo medikoei edo psikologikoei lotua, edo ez, egon zitekeen (ArtigasPallarès eta Díaz, 2013).

Ikusten denez, autismoak aurkezten duen itxura forma askotakoa da eta, hori dela eta, nahaste honen agerpen aukera zabala islatzeko Wing-ek asalduren espektro kontzeptua barneratu zuen (Happé, 2007). Honen iritziz, autismoak espektro bat sortzen du, hots, ez da kategorikoa (Baron-Cohen, 2010). Gauzak horrela, autismoa ondo zehaztutako kategoria bat baino hobe da garapenaren koadro desberdinetan hainbat mailatan aurkezten den continuum-tzat hartzea. Horietatik gutxiengoak (\% 10 baino gutxiago) Kanner-en autismoa definitzen duten ohiko baldintzek hertsiki biltzen ditu (Rivière, 2001). Beraz, autismo terminoaren barruan nahaste eta sindrome tarte oso zabala sartzen da, hauen artean aldakorrak dira eta kasu batzuetan portaera batzuk beste batzuk baino kaltetuago daude (Alonso Peña, 2009).

Larritasun maila sorta honi buruz hitz egiteko AEN kontzeptua erabili ohi da (ibidem), izan ere denboraren poderioz hau sendotzen joan da eta egun esparruko aditu gehiengoengatik onartua da (Artigas-Pallarès eta Paula, 2012). Terminoak autismo nahastea, Asperger nahastea, haurtzaroko nahaste desintegratzailea eta garapenaren nahaste orokor ez zehaztua barne hartzen du (Martos eta Burgos, 2013). Nahaste bakoitzak ondorengo seinale desberdinak aurkezten ditu (Cuadrado eta Valiente, 2005):

- Autismo nahastea: bizitzako lehen urteetan agertzen den garapenaren asaldura azaltzen du eta portaera sinple, errepikakor eta zenbaitetan arraroekin batera aurkezten da, itxuraz pertsonekiko interes gutxi erakutsiz. Ahozko lengoaiaren eskuratzean zein ulermenean eta gaitasun sinbolikoetan zailtasunak dituzte. Asaldura hauek bizitzan zehar irauten duten arren, sintomek aldeko bilakaera izan ahal dute esku-hartze goiztiar egoki bati esker. Nahaste hau autismo purua edo Kanner-en autismoa da eta continuum autistaren muturrean kokatzen da ekartzen duen arazeria dela eta.

- Asperger nahastea: ekintza sozialaren narriadura adierazgarria sumatzen da, baina bere identifikazioa berankorra da guztietatik berreskuragarriena den nahastea delako. Ez du lengoaiaren asaldura hain deigarria aurkezten, ahozko lengoaian gaitasun on bat dutelako eta hori dela eta, gainerako nahasteena baino egokiagoa den portaera lortzeko aukera dago. Ahozko lengoaiaren intonazioa monotonoa izan ohi da, eta ez ahozko komunikazioan baldartasuna erakusten dute. Kasu askotan jokoen arauak, harreman sozialetan dauden kodigo batzuk edo esanahi bikoitzak ez dituzte ulertzen eta beren interesak oso mugatuak izaten dira. Mugimenduaren garapenari buruz, hauen 
aldrebeskeria erakutsi ohi dute. Beren adimen gaitasunak zainduak dituzte eta, hazten diren heinean, esaldi konplexuak eta gaitasun sozialak erabiltzeko gai dira.

- Haurtzaroko nahaste desintegratzailea: hain ohikoa ez den nahaste honek bizitzako lehenengo hiru urteetan itxuraz normala den garapena erakusten du, baina gerokoan eskuraturiko gaitasunetan galera esanguratsuak azalduko ditu, ondorengo esparrutan behintzat: kognitiboa, hizkuntza, mugimendua, esfinterren kontrola eta jokoa.

- Garapenaren nahaste orokor ez zehaztua: aurreko diagnostikoen irizpideak argi eta garbi betetzen ez dituzten pertsonek barne hartzen dituen diagnostikoa da, bistakoa ez den zergati batekin.

\subsection{Prebalentzia}

Prebalentzia, epidemiologian erabilitako terminoa, azterlan dauden biztanle guztiei dagokienez gaixotasun bat pairatzen duten pertsonen proportzioa da (Espainiako Errege Akademia, 2015). Honen harira, duela urte gutxi arte autismoan argia zirudien gauza bakarretako bat prebalentzia zen. Hala ere, orain dela gutxiko zenbait ikerketek enigma berriak azaldu dituzte (Rivière, 2001).

Gauzak horrela, biztanlerian erregistratutako autismoaren eragina diagnostikoa eta definizioa nola egiten den araberakoa da. Ikerketa gehienetan eragina 4 eta 10 haur autista inguru 10.000 jaiotzako dagoela dirudi (Happé, 2007), biztanleriaren tamaina bereko laginarekin Asperger sindromearen 36 kasu eman ahal diren bitartean (Howlin, 1998). Hala ere, Wing-en eta Gould-en ikerketan asaldura sozialen, hizkerakoen eta portaerakoen hirukorako eragina 21 pertsona 10.000 biztanleko dela diote (Happé, 2007). Ildo honetatik, espektroaren ikuspuntutik abiatuz, beste autore batzuek autismoaren prebalentzia 10-20 pertsona 10.000 biztanleko (Baron-Cohen, 2010) eta 25 pertsona 10.000 biztanleko dela azaltzen dute (Fombonne, 2003). Nolanahi ere, azken urteetan Estatu Batuetan eta beste herrialdeetan AEN-rako deskribaturiko maiztasunak biztanleriaren \% 1era inguru ailegatu dira (Ameriketako Estatu Batuetako Psikiatria Elkartea, 2014).

Ikusten denez, eragin zehatza zehaztu ez bada ere, azken urteetan autismoaren eragina handitu da eta hau seguru aski nahastearen inguruko informazio hobeari, ikusmolde zabalagoari (Happé, 2007) eta diagnostikoa egiteko irizpideak gero eta hobeto ezagutzeari zor zaio (Cuadrado eta Valiente, 2005). Gainera, mutilengan neskengan baino ohikoagoa den asaldura da, neska bakoitzeko lau mutil inguruko proportzioan. Alabaina, eragina modu berean ematen da mota guztietako nazioetan, talde etnikoetan eta gizarte klaseetan (ibidem).

\subsection{Diagnostikoa}

Buruko asalduren kontzeptualizazioa homogeneizatzeko eta profesionalen artean irizpide diagnostikoak bateratzeko asmoz gidaliburu diagnostikoak landu zituzten, Osasun Mundu Erakundeak International Classification of Diseases (ICD) eta American Psychiatric Association-ek Diagnostics and Statistics Manual of Mental Disorders (DSM) (Artigas-Pallarès eta Paula, 2012). Sailkapen proposamen diferente hauek interesgarriak dira kategoria diagnostikoen gauzatzerako eta autismoa duten pertsonen beharren zehaztapenerako beharrezkoak diren zerbitzu desberdinez informatzen dutelako (Martos eta Burgos, 2013).

Aurretik aipaturiko hiru asalduren multzoa, Wing-en hirukoa bezala ezaguna dena, autismoaren diagnostikorako oinarria da (Martos eta Burgos, 2013). Hala ere, DSM 5-ek, gidaliburuaren azken bertsioak, harreman sozialaren eta komunikazioaren nahasteen irizpideak testuinguru desberdinetan komunikazio sozialean eta interakzio sozialean etengabeko gabezi bat bezala definitutako irizpide bakar batean multzokatuko ditu. Gainera, bertsio honek autismoa kontzeptualki sendotuko du, garapenaren nahaste orokorren izendapena AEN-gatik ordezkatuz (ArtigasPallarès eta Paula, 2012).

\section{Enplegua eta desgaitasuna}

Helduaroan kalitatezko bizitza baten sarbideak estatus sozial bat erdiestea dakar eta enplegu baterako sarbideak neurri handi batean estatus horretarako sarbidea ematen digu, beharbada oinarrizkoena (Verdugo et al., 2010). Beste modu batean esanda, gizabanakoaren beharren ikuspuntutik enplegua integrazio sozialerako bitarteko bat bezala ulertua izan behar da (Verdugo eta Jordán de Urríes, 2007). Enplegua pertsona guztientzat aukeren berdintasuna bermatzeko funtsezko elementua da. Bestalde, bizitza ekonomikoan, kulturalean eta sozialean herritarren parte-hartze betean modu erabakigarrian laguntzen $\mathrm{du}$, baita beren garapen pertsonalean ere (Osasun, Gizarte Zerbitzu eta Berdintasun Ministerioa, 2015a), sarritan lana independentziarako abiapuntua eta hautaketak egiteko trebetasuna da eta (Russell, 1997). Modu honetan, enplegua pertsona ororen, desgaitasunarekin edo desgaitasunik gabe, bizitza estiloa definitzen duen ezaugarrietako bat da. Enplegu motak, lortutako soldatak eta eskaintzen zaizkigun aukerek gure burua hautematen dugun moduan eta gizarteak baloratzen gaituen moduan zuzenean eragiten dute, baita maila ekonomikoan eta sozialean dugun askatasunean ere (Wehman et al., 1987).

Ikusten denez, soldata bat jasotzeko premia alde batera utzita, lan jarduerak ere onarpen soziala eta talde bateko kide izateko eta errealizatzeko beharra dakar (Jiménez Casas, 2006). Horrela, lan egiteko aukera ematea ez da soilik soldata baten lorpena, baizik eta bere balio sozialaren onarpena familiaren aldetik eta komunitatearen onespena (Verdugo eta Jenaro, 1993). 
Ildo honetatik, ikerketek desgaitasuna duten zein desabantaila sozialean dauden pertsonentzako enplegurako sarbidean sorburua duten ondorio positiboak agerian uzten dituzte. Gainera, modu esanguratsuago batean enpleguak bizi kalitatea eta desgaitasuna duten pertsonen balorazio soziala hobetzen duela eta beren autoestimua, gizarteratzea eta trebetasun sozialak handitzen dituela nabarmentzen dute (Verdugo et al., 2010). Hori dela eta, lan sartzea desgaitasuna duten pertsonen bizi kalitatea handitzeko erronka garrantzitsua da (Verdugo eta Jenaro, 1993).

Tamalez, desgaitasuna duten pertsonen kolektiboak lan-merkatuan parte hartze baxua du. 2013an desgaitasunen bat zuten 533.600 pertsonak aktibo zeuden, \% 37,4ko jarduera tasarekin; kopuru hau desgaitasunik gabeko biztanleriarena $(\% 77,2)$ baino ia 40 puntu gutxiagokoa zen. Horietatik 346.600 eta 187.000 pertsonak lanean eta langabezian zeuden, hurrenez hurren. Gauzak horrela, enplegu tasa $(\% 24,3)$ desgaitasunik gabeko biztanleriarena baino 32 puntu gutxiagokoa izan zen bitartean, langabezi tasak (\% 35) bederatzi puntutan gainditu zuen (Estatistika Institutu Nazionala, 2013). AEN-ri dagokionez, datuak are kezkagarriagoak dira, izan ere 2004 eta 2005 urte bitartean Autismo Andalucía-k eta Sevillako Unibertsitateak egindako ikerketa baten arabera, elkarrizketatutako 74 subjektutik soilik 2-k enplegu ordinariora sarbidea zuten (Saldaña et al., 2006). Hala ere, egun Espainia bezalako estatuetan autismoa duten pertsonen heren batek menpekotasun maila apur batekin lan egin dezakeela kalkulatzen da (Alonso Peña, 2009).

Desgaitasuna duten pertsonen enplegua sustatzera bideratutako ekimenak enplegu babestua edo enplegu ordinarioari gehitzea erraztera zuzenduak doazen arabera multzokatzen dira (Osasun, Gizarte Zerbitzu eta Berdintasun Ministerioa, 2015b). Batetik, enplegu babestuari dagokionez, desgaitasuna duen pertsonak lan jarduera bat jardun dezake, baina ez ohiko lan-merkatuan. Kasu hau enplegu zentro bereziena da, hauek jarduera produktiboa eta asistentziala burutzen duten zentro publikoak zein pribatuak dira eta langileentzat ordain bat bermatzen dute (ibidem). Alabaina, zerbitzu hauen izaera bereizitzat jo daiteke, bere helburua ez baita langileei desgaitasunik gabeko pertsonekin harremanak eskaintzea (Verdugo eta Jenaro, 1993).

Honekin batera, enplegu-enklabea Enplegu zentro bereziengatik garatutako jarduera produktiboaren eta komertzialaren ondorioz sortu da (Sánchez-Cervera, 2005). Modu honetan, desgaitasuna duten langile talde baten denboraldi baterako lekualdaketan datza, enplegu zentro berezi batetik ohiko lanmerkatuko enpresa baten instalazioetara, hain zuzen ere. Zentroa eta enpresaren arteko zerbitzuen errentamendu-kontratuaren bidez langileek jarduera produktibo bat garatzen dute. Azken helburua enplegu babestutik enplegu ordinariorako trantsizioa erraztea da (Osasun, Gizarte Zerbitzu eta Berdintasun Ministerioa, 2015b).
Bestetik, enplegu ordinarioaren barruan dauden neurrien artean, lehenengo eta behin, lanpostuen erreserba kuota eta kontrataziorako pizgarri ekonomikoak daude. Erreserba kuotak esan nahi du, 50 langile edo gehiago dituzten enpresek lanpostuen $\% 2$ desgaitasuna duten pertsonentzat gorde behar dutela. kontrataziorako pizgarri ekonomikoa, ordea, kontratazioengatik diru-laguntzetan, kuoten hobarietan eta salbuespenetan, kenketa fiskaletan eta lanpostuen moldaketari diru-laguntzetan datza. Bestalde, auto-enpleguaren sustapenari zuzendutako neurriak daude. Hauek enpresa-proiektuak eta norbere konturako langileen auto-enplegu proiektuak finantzatu eta lan elkartuko kooperatiben edo sozietate laboralen eraketarako diru-laguntzak ematen dituzte. Azaldutakoaz gain, enplegu publikorako ezarriak daudenak aipatu beharrekoak dira. Kasu honetan, administrazio publiko guztietan desgaitasuna duten pertsonentzako lanpostuen erreserba kuota \% 7 da. Gainera, aukeratzeprobetan hauek beharrezkoak dituzten moldaketak eta doikuntzak erabil ditzakete, baita lanpostuen hautaketan lehentasuna eta honen moldaera ere (Osasun, Gizarte Zerbitzu eta Berdintasun Ministerioa, 2015b).

Azkenik, enplegu ordinarioaren esparruan dagoen beste neurria laguntzadun enplegua da. Eredu hau 8oko hamarkadan Ameriketako Estatu Batuetan garatzen hasi zen (Wehman et al., 1987). Aitzitik, Espainian publikoki ezagutzera eman zen 1991ko abenduan, eredu honi buruz Mallorcan egindako lehenengo nazioarteko konferentzian, hain zuzen (Bellver, 1993). Bi urte beranduago, 1993an, Asociación Española de Empleo con Apoyo sortu zen. Elkartea Espainian eta Iberoamerikan programa hau garatzen duten erakundeek elkartzen, aholkatzen, indartzen eta laguntzen saiatzen da, baita administrazioekin baliozko solaskide bat izaten ere (Arenas eta González Celpa, 2010). Laguntzadun enpleguaren definizioari dagokionez:

Se entiende por empleo con apoyo el conjunto de acciones de orientación y acompañamiento individualizado en el puesto de trabajo, prestadas por preparadores laborales especializados, que tienen por objeto facilitar la adaptación social y laboral de trabajadores con discapacidad con especiales dificultades de inserción laboral en empresas del mercado ordinario de trabajo en condiciones similares al resto de los trabajadores que desempeñan puestos equivalentes (870/2007 Errege-Dekretua: 30.619).

Horrela, kolektiboaren barruan ez da soilik azaleratzen entzumen zein ikusmen desgaitasuna edo desgaitasun fisikoa duten pertsonen artean, baizik eta buruko gaitza, autismoa edo garunparalisia dutenekin ere (Verdugo eta Jordán de Urríes, 2007).

Aipatutako lan prestatzailea benetako sartzea gauzatzeaz eta lanpostuan entrenamendua eta beharrezkoak diren laguntzak emateaz arduratzen 
den pertsona izanda, txertatze prozesuan bere egitekoa oinarrizkoa da (Verdugo, Jordán de Urríes eta Bellver, 1998). Honek bere laguntza gutxitu dezake, esaterako autismoa duen pertsonak bere gaitasunetan eta lan giroko ezagutza orokorrean hobetuz gero (Jiménez Casas, 2006). Era honetan, lanpostuan dauden laguntza profesionalak denborarekin desagertu eta laguntza naturalengatik ordezkatuak izan behar dira, lankideak adibidez (Mank, Cioffi eta Yovanoff, 1997). Hori dela eta, laguntza naturalak programaren garapenaren funtsezko alderditzat hartzen dira (Jordán de Urríes, Verdugo eta Jenaro, 2006).

Bide honetatik, laguntzadun enplegua ez da desgaitasuna duen pertsona lanpostu batean jartzea beti lan prestatzaileaz lagunduta, ez da ingurune babestuetan gauzatutako lanei zuzentzen, ez du gaitasun gehiago dituzten pertsonak jartzen, ez da desgaitasuna duten pertsonak partaide diren instituzioen erantzukizunen uztea, ez da heziketa aurre-profesionala eta ez da heziketa ikastaro edo lan praktika modalitate bat. Horrela, laguntzadun enplegua eskolatik lan mundura eta bizitza independentera iragaite egokia aurrera eramateko ezinbesteko elementua da, autodeterminazioa, asebetetzea, enpleguaren mantentzea eta bizi kalitatea sustatuko duten laguntzak lanean emateko erreminta aproposena baita (Jenaro Río, 1998). Gainera, kolektibo honek gizarteari bere talentua eta esfortzua emateko gaitasuna eta borondatea duela erakusten da (Jordán de Urríes, Verdugo eta Vicent, 2005).

Beraz, programa hau desgaitasuna duten pertsonentzako dauden beste lan sartze modu tradizionaletatik desberdinduko litzateke, esaterako enplegu zentro bereziak (Jiménez Casas, 2006). Era honetan, enplegua ohiko enpresetan eta enplegu zentro berezietan alderatuta, lehenengoak bizi kalitate kota handiagoak eta langileen asebetetze eta beren bizitzaren gaineko kontrol pertzepzio gehiago ematen du (Verdugo et al., 2010).

Esandakoarekin batera, badaude beste neurri batzuk, zentro okupazionalak kasu, zehazki enplegu mota bat ez direnak, baizik eta asistentziazko ekintza (Osasun, Gizarte Zerbitzu eta Berdintasun Ministerioa, 2015b). Bertan lanaren inguruan orientatzen zaie, beren ikasketak sendotzeko ekintzak egiten dituzte eta mota sozialeko trebetasunak lantzen dira. Zentro hauen bidez pertsona batzuek laguntzak aintzat hartuz lan-merkatu ordinariora sartzeko aukera izango dute, eta beste batzuk enplegu zentro berezi batera ailegatuko dira beren ekintza inguru antolatuago batean jarduteko (Cuadrado eta Valiente, 2005). Hala ere, zentro okupazional batean dagoen desgaitasuna duen pertsonaren egoera ulertu behar da, desgaitasun fisikoa edo mentala duten pertsonez bakarrik inguraturik dagoena eta lan ordaindua egiteko aukerarik ez duena (Verdugo eta Jenaro, 1993).

Ildo honetatik, AEN duten helduen bizitza egoerari eta testuinguruari buruzko ikerketek, orokorrean, gizarte, komunitate eta bereziki lan integrazio eskaseko egoera erakusten dute (Álvarez, Cappelli eta Saldaña, 2008). Gauzak horrela, lanean sartzeko zailtasun bereziak dituzten kolektiboen artean AEN duten pertsonek zenbaitetan aparteko arazoei aurre eman behar diete. Beren desgaitasunak lanmerkatura sartzea zailtzearekin batera, biztanleriak nahaste hauen inguruan izan ahal duen ezjakintasun orokorrak hesiei aurre egitea ekartzen die, esaterako onarpenik eza lan inguruneetan. Modu honetan, batzuetan zailtasunak eskaintzen edo bete gabeko postuen sarbidean hasten dira: ez dituzte jendearen arrazoiak edo asmoak ulertzen eta ez dira gai gainerakoengan jokaerak aurreratzeko eta honek hautaketa elkarrizketa baten aurrean harridura sortzen du (Álvarez, 2011).

Izan ahal dituzten zailtasun nagusien artean, maila diferenteetan, komunikazioan trabak, modu autonomoan lan egiteko mugak, jokaera eredu desegokiak, portaera obsesiboak eta ohituretan aldaketak egiteari erresistentzia daude (Howlin, 2004). Hori dela eta, enplegu ordinario bat lortu ondoren sozialarekin, komunikazioarekin eta malgutasunarekin erlazionatutako eremuetan dituzten asaldurek pertsona hauentzat erronka garrantzitsua dakarte (Meyer, 2001). Hala ere, AEN duten pertsonek izan ohi dituzten ezaugarri batzuk baliotsuak dira enpresentzat. Esaterako, duten desgaitasunak iruzurrak eta esanahi bikoitzak ulertzea galarazten die eta horrek langile zintzoak, argiak eta leialak bihurtzen ditu. Gainera, askok izugarri zorrotzak dira eta zehaztasun maila altua dute (Álvarez, 2011). Hori dela eta, portaera autistek modu eraginkor batean lan egiteko edo esleituriko zereginak burutzeko gaitasunei eragiten ez dietela dirudi (Alonso Peña, 2009).

Esandakoak esanda, autismoa duten pertsonen artean enplegua izateko aukerak gaitasun sozial eta komunikatibo handiagoak dituzten pertsonen kasuan gehitzen dira. Beren bokaziozko jarrerak, nahiak eta, era berean, egiazko aukerak zeintzuk diren ikusi behar da lanerako trantsizioa planifikatu ahal izateko (Cuadrado eta Valiente, 2005). Beraz, autismoa duten pertsonen artean gaitasun gehiago dutenak bizitza independentea eramateko gai dira, gainbegiratze gabeko lanarekin, alabaina, ohikoagoa da ikuskatutako lana (Baron-Cohen eta Bolton, 2003).

Ikusten denez, autismoa duten pertsonen lanerako eskubidea funtsezkoa da eta horretarako, eginbeharreko lana esanguratsua eta era askotakoa izan behar da, beren zailtasun pertsonalak beti kontuan izango dituena (Jiménez Casas, 2006). Gauzak horrela, laguntzadun enplegua pertsona hauen beharrei erantzuna emateko sortu zen (Verdugo eta Jenaro, 1993), hau AEN duten pertsonen beharren perfilera hobekien egokitzen den metodologia baita (Cuesta Gómez eta Martínez Martín, 2012). 


\section{Entremanos elkartea}

AEN zein sustapen soziolaborala esparruetan lan egiten duen elkarte bat Entremanos da. Hau 2001ean Apnabi-n, Bizkaiko autismoa eta beste AEN-k dituztenen gurasoen elkartean, zeuden familiek kolektibo honi lan aukerak eskaini behar zaizkiola erabaki ostean sortu zen (Apnabi, 2015). Gauzak horrela, Apnabi-k bultzatutako eta babestutako elkarte honen helburua desgaitasuna duten pertsonentzat, batik bat AEN duten bizkaitarrentzat, lan aukerak sortzea da (Entremanos, 2015C).

Horretarako, Entremanos elkarteak hiru programa eskaintzen ditu. Batetik, zentro okupazionalak AEN duten pertsonei beren garapen soziolaboralean laguntzea du helburu, beti ere bakoitzak dituen gaitasunak aintzat hartuz. Bestetik, enplegu zentro bereziaren bitartez desgaitasuna duen pertsonari lan egonkortasuna, garapen profesionala eta bizi kalitatea eskaintzea bilatzen da (Entremanos, 2015a). Azkenik, elkarte honek kolektiboa ohiko lan ingurunetan sartzearen aldeko apustua egin duela azpimarratzekoa da eta hori dela eta, laguntzadun enpleguaren estrategia erabili eta garatzen du (Entremanos, 2015b). Modu honetan, banan-banako zerbitzu eta ekintza multzoa eskainiz, pertsonak ohiko lan-merkatuko enpresa batean sartu eta bertan jarraitu eta mailaz igotzea da helburua, prozesu horretan profesionalen zein beste laguntza mota batzuk kontuan izanda (Entremanos, 2015a). Gaur egun, programa honen bitartez bederatzi pertsona ${ }^{2}$ ohiko enpresetan txertatuta daude.

Azken finean, honekin guztiarekin elkarteak AEN duten helduak gizartearen eragile aktibo bilakatzea nahi du, bai eguneroko bizitzan parte hartzeko bai gizarteak pertsona hauen lana aitortzeko (Entremanos, 2015b).

\section{Ikerketaren diseinua}

\subsection{Ikerketaren helburu eta hipotesiak}

Ikerketaren helburu nagusia honakoa da:

- $\quad$ AEN duten pertsonak laguntzadun enpleguaren bidez enplegu ordinarioan nola txertatu diren aztertzea.

Lan hau garatzeko hipotesi batzuetatik abiatu gara:

- AEN duten pertsonak:

- Enplegu ordinario bat izateko gai dira.

- Enplegu ordinario bat izateak gizarteratzeko bidea zabaltzen die.

- Laguntzadun enplegua enplegu ordinario bat lortzeko bitartekoa da.

\footnotetext{
${ }^{2}$ Entremanos elkarteko arduradunari egindako elkarrizketa.
}

\subsection{Metodologia}

Gauzatu den ikerketa kualitatiboa izan da. Metodologia kualitatiboa egoera bakarren eta partikularren ulerkuntzarantz orientatzen da eta agenteek berek gertaerei ematen dieten esanahi eta zentzu bilaketan, eta ikertzen diren gizabanakoek edo talde sozialek zenbait fenomeno edo esperientzia nola bizi eta esperimentatzen dituzten arreta jartzen du (Rodríguez Gómez eta Valldeoriola, 2009). Kasu honetan, AEN duten pertsonen lan munduaren txertaketa prozesura hurbilketa bat da.

Horretarako, triangelaketa prozedura erabili izan da, hots, metodo, ikuspegi edo datu mota desberdinen erabilera ikerketa berean (García Galera eta Berganza, 2005).

\subsubsection{Informazio iturriak}

Iturrien hautaketa Entremanos elkarteko arduradunarekin adostu izan da, informazio esanguratsuena lortzeko asmoarekin.

Ildo honetatik, hautatutako lagina AEN duten hiru langileak eta beren testuingurua da; zehazki, Entremanos elkarteko arduraduna eta laguntzadun enplegua programan lan egiten duten hiru lan prestatzaile, AEN duten hiru pertsonak egondako lantokiko bi arduradun eta hiru senide.

Era honetan, AEN duten hiru pertsona horiek, 1, 2 eta 3 kasuak bezala identifikatzen direnak, bizi izandako hiru enplegu prozesuen esperientziak aintzat hartu dira; Enplegu ordinarioa, laguntzadun enplegua eta zentro okupazionala. enplegu ordinarioari dagokionez, A eta B kasuek lurrin denda batean lan egin dute eta $\mathrm{C}$ kasuak, aldiz, garbiketa enpresa batean.

\subsubsection{Datu bilketarako teknika}

Informazio bilketarako erabilitako teknika elkarrizketa sakona izan da. Teknika hau ikertzaileen eta informatzaileen arteko topaketak dira eta informatzaileek beren bizitzei, esperientziei edo egoerei buruz dituzten ikuspegien ulerkuntzarantz bideratuak daude. Elkarrizketa sakonak ez dira galderen eta erantzunen truke formal bat, baizik eta berdinen arteko hizketa baten eredua jarraitzen dute (Taylor eta Bogdan, 1987).

Gauzak horrela, ikerketan burututako elkarrizketak aurrez aurre eginak izan dira eta hurbiltze motak izaera indibiduala eta estua izan du, kasu batean izan ezik zeinean bi senide batera elkarrizketatu diren. Hala ere, zenbait kasutan emailez eta telefonoz gauzatzeko beharra egon da. Esaterako, erabiltzaile batek komunikatzeko dituen arazoak direla eta elkarrizketa emailez ere egitea egokiagoa ikusi da, baliabide honen bitartez iritziak eta sentimenduak espresatzeko erosoago sentitzen baita. 
Informazio iturri desberdinak direla eta, kasu bakoitzerako gidoi bat jarraitu izan da. Hauek guztiak erdi-egituratuak izan dira, hots, elkarrizketa bakoitzeko momentuko gaiei egokitzen joan dira, ikerketaren helburuei, elkarrizketatuei eta prozesuaren uneari moldatuz.

\subsubsection{Datuen azterketa}

Informazioaren analisia egiteko metodo hipotetikoadeduktiboa erabili da (Fierro, 2004). Horretarako, ikerketaren ildo azpimarragarriak aukeratu eta horien arabera kategoriak egin dira. Honen ostean, bildutako datuen ardatz nagusiak hartuz analisia egin da eta, azkenik, emaitzak atera dira.

\section{Emaitzak}

Emaitzak aztertutako hiru lan esperientzien arabera azaltzen dira. 1. Koadroan elkarrizketatutako pertsonei egokitu zaizkien kodeak aurkezten ditugu.

1. Koadroa. Elkarrizketetan erabilitako kodeak
\begin{tabular}{|l|l|}
\hline Langilea $\left(\mathrm{L}_{1}\right)$ & Entremanos-eko arduraduna $(\mathrm{EA})$ \\
\hline Langilea $\left(\mathrm{L}_{2}\right)$ & Lan prestatzailea $\left(\mathrm{LP}_{1}\right)$ \\
\hline Langilea $\left(\mathrm{L}_{3}\right)$ & Lan prestatzailea $\left(\mathrm{LP}_{2}\right)$ \\
\hline Senidea $\left(\mathrm{S}_{1}\right)$ & Lan prestatzailea $\left(\mathrm{LP}_{3}\right)$ \\
\hline Senidea $\left(\mathrm{S}_{2}\right)$ & Lantokiko arduraduna $\left(\mathrm{LA}_{1}\right)$ \\
\hline Senidea $\left(\mathrm{S}_{3}\right)$ & Lantokiko arduraduna $\left(\mathrm{LA}_{2}\right)$ \\
\hline
\end{tabular}

Iturria: Egileen lana.

\subsection{Enplegu ordinarioaren esperientzia}

Aurkeztutako hiru pertsona hauen ibilbidea edozein dela ere, hirurek beti enplegu ordinario batean lan egiteko aldez aurretiko jarrera izan dute. Gainera, beren ingurukoei asmo hori adierazteaz gain, baliabideak ere bilatu izan dituzte:

Se ha presentado a entrevistas de trabajo de empresas que salían en información en El Correo (S2).

Tenía tan claro que quería trabajar que iba por Barakaldo preguntando en las fruterías a ver si necesitaban empleados (LP3).

Hori dela eta, enplegu ordinario bat izango zutela jakiterakoan izan zuten sentsazio orokorra poztasuna izan zen. Egun duten enplegu ordinarioari dagokionez, hiru kasuek jarrera baikorra mantentzen dutela azpimarratzekoa da:

Demuestra ante las compañeras una actitud superpositiva que ninguna de ellas tiene, le da importancia al trabajo (LP1).

Ikusten denez, beraientzat enplegua ez da igarokorra, baizik eta serioski hartzen dute eta harekin konprometitzen dira. Ildo honetatik, hirurek duten enplegua gustuko dutela eta gustura sentitzen direla baieztatu dute. Atsegin izateaz aparte, lantokiko arduradunek beren zeregina ondo betetzen dutela eta denboraren poderioz hobetuz joan direla diote:

Ahora tiene mucha más soltura en todas las tareas que realiza (LA1).

Honen harira, neurri batean edo bestean, enplegu ordinario bat izateak hirurengan modu berean eragin duela sumatu daiteke. Era honetan, enpleguak autonomia ekarri diela adierazi dute, baita autodeterminazioa ere:

Este trabajo me aporta autonomía para hacer la tarea por mí mismo (L1).

Allí estoy tomando decisiones, y nadie está detrás mío diciendo que haga una cosa u otra; yo sé lo que tengo que hacer $\left(L_{3}\right)$.

Sentipen hau beren ingurukoek ere hauteman dute, autonomia fase gehiago bilatzen ari direla diote eta:

Es como que ya ha conseguido el trabajo y ahora quiere más (LP3).

Ekarpen hau, aldi berean, segurtasunarekin lotuta doa, beren buruarengan segurtasuna ekarri baitie:

Está más erguida y se le nota más segura, me pregunta qué tiene que hacer (LA2).

Lo que más me chocó fue el día que la vi diciendo a una clienta una oferta que no le habían dicho que dijera, imagínate qué es eso para ella (LP2).

Aipaturiko azken testigantzak, gainera, etapa berriak komunikazioan nahiz elkarrekintzan izan ditzaketen zailtasunetan aurrera egitea ahalbidetu diela nabarmen uzten du. Beste etsenplu batzuei dagokienez:

Me ayuda a comunicarme con los clientes y a mantener una relación con las compañeras, por eso me veo con más habilidad a la hora de hablar (L1).

Como me cuesta hablar en público, me ayuda a tener más fluidez al hablar y a estar cómodamente con la gente de fuera (L2).

Jazotako aldaketa horiek bai lankideek bai

Entremanos elkarteko langileek ere sumatu dute:

Los primeros días, casi no hablaba; ahora en cambio, habla más y se le escucha la voz de manera más clara (LA2).

El hecho de que te venga y te hable directamente sin que tú le digas ya es un cambio (LP2).

Sus compañeros de trabajo están alucinados, dicen que parece otra persona, porque habla 
más, pregunta más, es más cercano, interacciona mucho más $\left(\mathrm{LP}_{3}\right)$.

Enplegu ordinariotik at interakzioa beren bizitza pertsonalera ere zabaldu den puntua da:

Está hablando más en casa (S2).

Honek guztiak hiru kasuetako langileek beren lankideekin duten harremana denboraren poderioz sendotu izana ahalbidetu du.

Me siento muy apoyado por ellos (L1).

Mis compañeras me apoyan y comprenden cómo soy y están pendientes de mí por si ocurre algo inesperado con alguna clienta; puedo confiar mucho en ellas (L2).

Modu honetan, hirurek egun erlazio ona mantentzen dutela baiezkoan egoteaz gain, beren ingurukoak harremana haratago doala sinetsita daude:

Cuando está por el pueblo dando una vuelta fuera de su horario de trabajo, pasa a saludarnos (LA2).

Nosotros, en el centro ocupacional, a pesar de tener mucha relación con él, no hemos llegado a tener ese nivel de confianza (LP3).

Halaz ere, egia da hasiera batean lantokiko langile batzuk ez zeudela guztiz ados lehenengo eta bigarren kasuko lan sartzeekin. Aitzitik, hirugarren kasuko lankideak pozez zoratzen zeuden:

Al principio, algunas compañeras estaban un poquito recelosas, pero con el tiempo se le ha dado la vuelta a la situación, se ha conseguido hacer un vínculo y una relación muy cercana $\left(\mathrm{LP}_{2}\right)$.

En un primer momento, todo era maravilloso, una acogida demasiado optimista y proteccionista ( $\left.\mathrm{LP}_{3}\right)$.

Azaldutakoarekin batera, enplegu ordinarioak beren seme-alabek gainerakoak bezala izateko duten grina azaleratu duela baieztatu dute. Gauzak horrela, gainerako pertsonen gisa sentitzea lortu dute, hots, lan taldearen partaide bat gehiago kontsideratzen dira eta horrek asebetetzea eman dielakoan daude:

Se siente mucho mejor, el estar con gente 'normal' le sienta muy bien (S1).

Con el trabajo se ve que es útil para la sociedad (S2).

Ser como los demás, ser uno más (S3).

Gogobetetze beteriko bizitza berri honek, orain arte beren buruen gainean izan ez dituzten erantzukizunak erdiesteko abagunea ahalbidetu die:
Se está viendo capaz de hacer cosas que nunca antes se hubiese imaginado que podía hacer (LP2).

Izan ere, nola senideak hala Entremanos elkarteko langileak ongi bideratuak doaz:

Me siento como una trabajadora más, porque hago lo mismo que ellas (L2).

Me siento como los demás, yo me arreglo muy bien solo (L3).

Honek guztiak, ezbairik gabe, lotura zuzena dauka hiru kasuen auto-estimuarekin:

Anímicamente está mucho mejor (S2).

Gainera, hiru kasuetako langileak bat datoz duten soldata egokia dela eta enplegu ordinario bat izateak independentzia ekonomikoa dakarrela baieztatzean:

Me puedo comprar algún caprichito, por ejemplo, mi nuevo móvil (L1).

Ildo honetatik, oraingoz independizatzeko abagunea ez badute ere, etorkizunean aukera izatekotan alde batera uzten ez duten ideia da, normalizazio seinale bat dena.

Etorkizunari begira, hiru kasuetako langileek enplegu ordinario batean lan egiten jarraitu nahi dutela azpimarratzen dute:

Quiero seguir trabajando, porque esto es un trabajo de verdad (L3).

Haatik arreta egun duten enpleguan jarriz hiruren iritziak ez dira bat etortzen:

Estoy fijo y quiero quedarme en ese puesto de trabajo hasta jubilarme (L3).

Si me dieran a elegir, elegiría algún trabajo de oficina, porque me siento aún más cómoda (L2).

Tengo claro que sería en una tienda, porque es en lo que me he formado y especializado, es mi trabajo ideal (L1).

Gainera, beren ingurukoek hiru kasuetako langileek lanpostuetan iraungo dutela sinetsita daude. Halere, lehenengo zein bigarren kasuak gainditze gaitasuna badute ere, erantzukizun gehiago izatea zaila gertatu liteke:

Le pueden asignar más tareas, pero más responsabilidades en cuanto a toma de decisiones respecto a otras personas, pues siendo realistas, quizás no (LP1). 


\subsection{Laguntzadun enpleguaren esperientzia}

AEN duten pertsonen ezaugarriek lan sartze hori zaildu dezakete eta horri aurre egiteko laguntzadun enpleguaren garrantzia aipatzekoa da. Hiru kasu hauei lagundu dieten lan prestatzaileek, Entremanos elkarteko langileak direnak, kasu hauen segimendu handia egin behar izan dute:

Al principio, estaba toda la jornada y desglosábamos las tareas; cuando veía que una tarea ya estaba interiorizada, pasábamos a otra y así sucesivamente (LA1)

Hori dela eta, profesional hauen egotea ezinbestekotzat suertatzen da:

Somos como un foco encima de la cabeza de la persona: siempre tienes que estar adelantándote a los pasos que van a venir (LA2)

Alabaina, hiru kasuek hasiera batean lan prestatzailearen figura guztiz gogoko ez zutela esan beharra dago:

A él no le gustaba, bueno, a ninguno le gusta, yo creo, la figura del preparador laboral, que esté ahí marcándole (LA3).

En un principio, ella quería sin el apoyo, pero sí es verdad que muchas veces dice que, con el apoyo, se ve mucho más segura (S2).

Denboraren poderioz, hiru kasuetako langileek zereginak barneratu eta lan prestatzaileek hauen lankideekin zituzten harremanak handitu dituzten bitartean, jarraipenak gutxitzen joan dira, gaur egungo esku-hartzea gutxienekoa izatera bilakatuz. Jarraipen laguntza horren seinale dira:

Una vez a la semana la llamo para ver qué tal va todo, y voy cada quince días más o menos, según las necesidades que vayan saliendo (LA2).

Voy, por lo menos, una vez al mes, y hablo con los compañeros; éstos también me llaman en caso de que surja alguna cosa (LA3).

Azken kasu honi dagokionez, atzera egitea beranduxeago eman da:

A pesar de haber apoyos naturales, él trabaja solo, y en las tareas del día a día, no tiene ninguna persona que le oriente (LA3).

Gauzak horrela, lanpostuak zailtasun gehiago ekarri ahal lizkiokeen arren, egoera hau egiaz jazotzen da langileak duen laguntzarekin bere lana aurrera eramateko gai delako. Ildo honetatik, hiru kasuetan lan prestatzaileek emandako laguntza lankideen laguntza naturala bilakatu dela nabarmentzekoa da:

Las compañeras están siendo un gran apoyo para él, sobre todo una de ellas, que es la que le orienta en el día a día, es su apoyo natural (LA1).
Hoy en día, puedo decir que todas sus compañeras son apoyos naturales, le pueden orientar en cualquier momento (LA2).

Hiru kasuetako langileen pentsamendua ere bide beretik doala esan beharra dago, gainera hauentzat lankideengandik jasotako laguntza behar bestekoa da:

Ahora, en la tienda me ayudan mis compañeras, y por ahora, con la ayuda que tengo, para mí es suficiente (L2).

Les pregunto a mis compañeras cómo se hacen las cosas y me responden correctamente; por eso de momento no me gustaría recibir más apoyo, me veo bien como estoy ( $(\mathrm{L} 1)$.

Prozesu luze honetan hiru kasuetako langileek izandako laguntza anitza izan den arren, hauek hamaika zailtasun izan dituzte, esaterako beren enpleguan malgutasuna izan dute oztopo, AEN duten pertsonen ezaugarria dena:

Es muy cuadriculado, y si el ordenador falla, ya el margen de movimiento es muy corto, se pone nervioso y no puede continuar $\left(\mathrm{LP}_{1}\right)$.

Muchas veces es muy poco flexible, y eso le hace retrasarse; por ejemplo, le hemos dicho que si va justo de tiempo, que revise si está limpio o no, pero él lo limpia directamente (LP3).

Modu honetan, izandako trabak gainditzeko egokitzen franko egin behar izan dituzte, eguneroko ohikeria jarraitzea erraztu duena:

Se hicieron muchas adaptaciones para que fuera cogiendo rutinas, secuenció mucho el proceso con dibujos de pictogramas e incluso tuvimos que hacer con pelotitas caminos para que él los memorizara y fregase así bien los suelos (LP3).

Cuando le preguntaban algo, se bloqueaba, y por eso se le ponía un reto pequeñito cada día, por ejemplo, ofrecer su ayuda a tres personas. Además, preparamos frases por si no se siente con la capacidad de contestar, para que derive a esas personas hacia sus compañeras (LP2).

Oztopoak oztopo, bai Entremanos elkarteko langileek bai lantokiko arduradunek hiru kasuak enplegu ordinariora ederki egokitu direla esanez bat egiten dute. Gainera, elkarrizketatuek laguntzadun enpleguak enplegu ordinariorako sarbidea ahalbidetzean, desgaitasuna duten pertsonen inklusioa ere lortzeko bidea ematen duela uste osoa dute:

El empleo ordinario es el puente hacia la inclusión, el hecho de que se pueda estar en un espacio donde está todo el mundo ( $\left.\mathrm{LP}_{2}\right)$.

Es la única forma de que la persona se sienta como uno más sin sentirse señalado, y encima dando notoriedad a sus fortalezas (LP1). 
Azken finean, AEN izan ala ez, laguntzadun enpleguak pertsona guztien arteko berdintasuna sustatzen du:

Entiendo que lo mejor es la normalidad (LA1).

Hay que hacer que trabajen igual que el resto, que lo hagan en las mismas condiciones y que ganen el mismo salario que ganaría cualquier otra persona. Por ello, el empleo con apoyo es una experiencia vital en igualdad de condiciones y ofrece la posibilidad de ejercer todos los derechos (EA).

Halaz ere, tamalez, jorraturiko esparru honetan oraindik ere bide luzea egiteke dago, izan ere horretarako gizarteak oraindik eskaintzen ez duen prestasunari buelta eman beharko lioke:

No estamos concienciados de que estas personas también tienen capacidades y derechos (LA2).

Horren adibide esanguratsua senide batek bere lantokian, hain zuzen ere, bizitako esperientzia da:

Yo he trabajado en una empresa donde trabajaba un chico con una discapacidad que tenía apoyo, y mis compañeros no le comprendían (S2).

Horretarako, bigarren kasuko senidearen hitzetan laguntzadun enpleguak enpresa guztietan nahitaezkoa izan beharko luke. Ildo honetatik, Entremanos elkarteak jadanik horretan dihardu:

Estamos luchando para que el empleo con apoyo sea visualizado por las empresas, instituciones y sindicatos (EA).

\subsection{Zentro okupazionalaren esperientzia}

Zentro okupazionalean egondako denborari dagokionez, Entremanos elkarteko langileen esanetan bertan hiru kasuetako langileek modu gogotsu batean parte hartu izan dute. Bide honetatik, bai lehenengo bai bigarren kasuek egun lurrin denda batean lan egiten dutela aintzat hartuz, bitxia da azken kasu hau Entremanos elkarteko dendan egon ez izana:

Nunca estaba en la tienda, lo social le podía (LP2).

Honen harira, Entremanos elkarteko langileek hiru kasuak zentro okupazionalean gustura sentitzen zirela adierazi dute. Hala ere, adiskideekin izandako adiskidetasuna dela eta, horren inguruan zalantza egiteko premia ikusi da. Batetik, Entremanos elkarteko langileen aldetik arazorik ez da egon:

Creo que se sentía bien con los compañeros, que se identificaba con ellos (LP1).

Con los compañeros, nunca ha tenido ningún problema; se ve que éstos la tenían aprecio (LP2).
Bestetik, ostera, senideen aburuz adiskideekin zituzten arazoak zentro okupazionala arbuiatzearen abiapuntua ziren:

No quería ir al centro ocupacional, a veces venía [diciendo] que había tenido algún problema con algún compañero (S1).

No le gustaba el centro ocupacional, decía que eran raros sus compañeros $\left(\mathrm{S}_{3}\right)$.

Nolanahi ere, elkarrizketatuek zentro okupazionalak enplegu ordinario bat aurkitzeko duen baliagarritasuna sumatzen dute.

En el centro ocupacional, he aprendido a estar concentrado, a trabajar tranquilo y relajado, y a hacer caso a lo que me digan $\left(\mathrm{L}_{3}\right)$.

De todo lo que he aprendido, han ido viendo en qué me desenvuelvo mejor (L1).

Había cosas que ya nos daban pistas de cómo iba a ser él en el empleo con apoyo (LP3).

\section{Ondorioak}

Ikerketaren ildo azpimarragarriek ondorio orokor batzuk begi-bistan utzi izan dituzte. Lehenengo eta behin, aurretik zehazturiko hipotesiak zeharo bete direla nabarmentzekoa da.

Batetik, AEN duten pertsonak enplegu ordinario bat izateko gai dira. Horrela, dituzten ezaugarriek hasiera batean lan txertatzean zailtasunak ekarri dizkieten arren, laguntza egokia izanez hauek desagerrarazteko kapaz direla erakutsi dute. Honen harira, AEN duten pertsonen jarrerarekin ez dago zalantzarik desgaitasun bat izatea ez dela oztopo lan egin nahi izateko, areago, enplegu baten bilaketa aktiborako eragingarria izan daiteke. Azken finean, beste edozein pertsona bezala, enplegu bat bilatzeko zein lortzeko premia dute.

Bestetik, enplegu ordinarioak gizarteratzeko bidea zabaldu diela aitortu beharra dago, egia esanda honen bitartez beren garapen pertsonalerako ezinbestekoak diren aspektuak, autonomia eta segurtasuna kasu, bereganatu dituzte, baita nahasteak komunikazioan zein elkarrekintzan eragiten dien trabak gainditu ere. Hau, ezbairik gabe, sekulako ekarpena da interakzio sozialean nahiz komunikazioan zailtasunak izatea AEN-ren seinale argiak direla kontuan hartzen badugu.

Labur esanda, gertaera honek mundu ezezagun baterako ateak irekitzen dizkie, izan ere menpekotasun parte batekin apurtzeak, besteak beste, norbera bere burua ezagutzea eta noraino hel daitekeen ikustea dakar, inolako bereizketarik pairatu gabe eta ordura arte ukaezinak ziren erronkak planteatuz. 
Azkenik, laguntzadun enplegua enplegu ordinario bat lortzeko bitartekoa dela argi baino argiago geratu da. Ildo honetatik, diziplina arteko taldearen barruan lan prestatzailea alde guztien arteko bitarteko eztabaidaezina dela erakutsi da, prozesu osoan zehar pertsona bideratzen duen etengabeko orientatzailetzat hartu beharra dago eta. Gainera, ez da ahaztu behar profesional honen laguntza naturala bilakatu dela, edozein enpresako langileen arteko laguntza baino ez dena. Hori dela eta, baliteke egiaz gakoa horretan egotea; irudi hau espresuki beraientzat sortua ez dela ikusten dute eta honek ezer inposatzen ez zaiela ustea dakar.

Zentro okupazionalari dagokionez, ikerketa honek hau helburua ez dela agerian uzten du, enplegu ordinarioranzko bidean dagoen erreminta bat baino ez baita. Alabaina, honek ez du esan nahi enplegu ordinariorako sarbidea ukatzen dela aurretik hemendik pasatu ez baldin bada.

Bestalde, etorkizunari begira erronka batzuk planteatzeko premia bistakoa da. Esaterako, ikerketaren esparruan laguntzadun enpleguak eskaintzen dituen onurak azpimarratzeaz gain, adituek egoera hau zuzenean eragiten dieten pertsonei beren esperientziak partekatzeko abagunea eman behar diete, desgaitasuna duten pertsonen egoera lan esparruan erabat normalizatzea aldarrikatuz. Honekin batera, lanpostuan beren ardura are handiagoa izatea nola lor dezaketen planteatzeko beharra ere du.

Hori gutxi balitz bezala, gizarteratzea sustatu nahi bada lanpostuetan egoera berezien sorkuntza saihestea ezinbestekoa izango da eta horretarako, segregazioa sustatzen duten neurriek apurka beren presentzia murrizten joan beharko dute, enplegu ordinarioaren aldeko apustua eginez.

Normalizazio prozesu honetan, modu eraginkorrean bidezkoagoa den gizartea garatzeko asmotan instituzioek zein enpresa ordinarioek parte hartu ez ezik, herritar guztiek ere hartu behar duten konpromisoa da. Ikusi den moduan, ez mesfidantza ez babes gehiegi portaerek ez dute lan txertatzea errazten, kasu hauetan pertsona langilearen gainetik jartzen baita. Jokabide hauek, kolektibo honekin zintzotasunez ez jokatzea dakartenak, gizartearen kontzientziazio faltagatik izan daitezke eta horrek, tamalez, beren eskubideak urratzea dakar. Honek guztiak oraindik egiteke dagoen bidea agerian uzten du. 


\section{Aipatutako bibliografia}

ALONSO PEÑA, J. R. (2009): Autismo y síndrome de Asperger: guía para familiares, amigos y profesionales, 2. ed., Salamanca, Amarú Ediciones.

ÁLVAREZ, R. (2011): "Servicio de integración laboral para personas con TEA en Andalucía", in ASOCIACIÓN ESPAÑOLA DE PROFESIONALES DE AUTISMO, Investigación e innovación en autismo: premios 'Ángel Rivière' 2010, quinta edición, Zaragozako Aldundia, 159-233 or.

ÁLVAREZ, R.; CAPPELLI, M.; eta SALDAÑA, D. (2008): Quiero trabajar: empleo y personas con trastornos del espectro autista, Sevilla, Autismo Andalucía.

APNABI (2015): “Zerbitzuak. Sustapen Soziolaboraleko Eremua" [<http://www.apnabi.org/eu/ servicios/area-de-promocion-sociolaboral/>].

ARENAS, M. L.; eta GONZÁLEZ CELPA, R. (2010): “El preparador laboral en el empleo con apoyo", Educación y Futuro, 23. zb., 43-50 or.

ARTIGAS-PALLARÈS, J.; eta DÍAZ, P. (2013): “Bases biológicas de los trastornos del espectro autista", in ALCANTUD MARÍN, F. (koord.), Trastornos del espectro autista: detección, diagnóstico e intervención temprana, Madril, Pirámide, 35-60 or.

ARTIGAS-PALLARÈS, J.; eta PAULA, I. (2012): “El autismo 70 años después de Leo Kanner y Hans Asperger”, Revista de la Asociación Española de Neuropsiquiatría, 115. zb., 567-587 or.

AMERIKETAKO ESTATU BATUETAKO PSIKIATRIA ELKARTEA (2014): DSM-5: Manual diagnóstico y estadístico de los trastornos mentales, 5. ed., Madril, Editorial Médica Panamericana.

BARON-COHEN, S. (2010): Autismo y síndrome de Asperger, Madril, Alianza.

BARON-COHEN, S.; eta BOLTON, P. (2003): Autismo: una guía para padres, Madril, Alianza.
BELLVER, F. (1993): “El empleo con apoyo en España”, Siglo Cero, 148. zb., 55-61 or.

COLEMAN, M.; eta GILLBERG, C. (1989): El autismo: bases biológicas, Bartzelona, Martínez Roca.

CUADRADO, P.; eta VALIENTE, S. (2005): Niños con autismo y TGD: ¿cómo puedo ayudarles?, Madril, Síntesis.

CUESTA GÓMEZ, J. L.; eta MARTíNEZ MARTíN, M. A. (2012): "Una mirada hacia el futuro", in MARTíNEZ MARTíN, M. A.; eta CUESTA GÓMEZ, J. L. (koord.), Todo sobre el autismo: Los trastornos del espectro del autismo (TEA). Guía completa basada en la ciencia y en la experiencia, Tarragona, Altaria, 505-519 or.

ENTREMANOS-ASOCIACIÓN PARA LA PROMOCIÓN SOCIOLABORAL (2015a): "Eskaintzen ditugun programa eta baliabideak" [<http://www. entremanos.org/eu/s].

- (2015b): "Definizioa eta egitura" [<http://www. entremanos.org/definizioa-egitura/>].

- (2015c): “Nortzuk gara” [khttp://www.entremanos.org/ nortzuk-gara/>].

ESPAINA (2007): “Real Decreto 870/2007, de 2 de julio, por el que se regula el programa de empleo con apoyo como medida de fomento de empleo de personas con discapacidad en el mercado ordinario de trabajo", Boletín Oficial del Estado, 168. zb., 2007-7-14, 30.61830.622 or. [khttp://www.boe.es/buscar/doc. php?id=BOE-A-2007-13588>].

ESPAINIAKO ERREGE AKADEMIA (2015): “Prevalencia”, in ESPAINIAKO ERREGE AKADEMIA, Diccionario de la lengua española [«http://dle.rae. es/?id=U8xd4iz>].

ESTATISTIKA INSTITUTU NAZIONALAK (2013): “El empleo de las personas con discapacidad” [ [ hhttp://www. ine.es/prensa/np883.pdf)]. 
FIERRO, A. (2004): "Sobre hipótesis y método", Revista de Psicología General y Aplicada, 4. zb., 379-394 or.

FOMBONNE, E. (2003): "Epidemiological surveys of autism and other pervasive developmental disorders: An update", Journal of Autism and Developmental Disorders, 4. zb., 365-382 or.

GARCÍA GALERA, M. C.; eta BERGANZA, M. R. (2005): “El método científico aplicado a la investigación en comunicación mediática”, in BERGANZA, M. R.; eta RUIZ SAN ROMÁN, J. A. (koord.), Investigar en comunicación: guía práctica de métodos y técnicas de investigación social en comunicación, Madril, McGraw-Hill, Interamericana de España, 19-42 or.

GARCÍA-VILLAMISAR, D. (2006b): "Sintomatología y clasificación del espectro del autismo", in GARCÍA-VILLAMISAR, D. (zuz.), Educación de personas adultas con autismo, Madril, Madrilgo Erkidegoa, 31-52 or.

HAPPÉ, F. (2007): Introducción al autismo, Madril, Alianza.

HOBSON, R. P. (1995): El autismo y el desarrollo de la mente, Madril, Alianza.

HOWLIN, P. (2004): Autism and Asperger Syndrome: Preparing for Adulthood, Londres, Routledge.

- (1998): "Practitioner review: Psychological and educational treatments for autism", Journal of Child Psychology and Psychiatry, 39. zb., 307322 or.

JENARO, C. (1998): "Transición de la escuela al trabajo y a la vida independiente”, Estudios de Juventud, 43. zb., 31-45 or.

JIMÉNEZ CASAS, C. L. (2006): "El derecho al trabajo de las personas con autismo", Maremagnum, 10. zb., 123-134 or.

JORDÁN DE URRÍES, F. B.; VERDUGO, M. A.; eta JENARO, C. (2006): "Tipicidad, calidad de vida y mejora de los resultados en empleo con apoyo", in VERDUGO, M. A. (zuz.), Cómo mejorar la calidad de vida de las personas con discapacidad: instrumentos y estrategias de evaluación, Salamanca, Amarú, 143-176 or.

JORDÁN DE URRÍES, F. B.; VERDUGO, M. A.; eta VICENT, C. (2005): Análisis de la evolución del empleo con apoyo en España, Documentos saila, 59/2005 zb., Madril, Ezgaitasunen Errege Patronatua, 7-8 or.

KANNER, L. (1993): “Trastornos autistas del contacto afectivo", Siglo Cero, 149. zb., 5-25 or.

MANK, D.; CIOFFI, A.; eta YOVANOFF, P. (1997): “Analysis of the typicalness of supported employment jobs, natural supports, and wage and integration outcomes", Mental Retardation, 35. zb., 185197 or.

MARTÍN BORREGUERO, P. (2004): El síndrome de Asperger: ¿excentricidad o discapacidad social?, Madril, Alianza.

MARTOS, J. (2000): “Trabajos en autismo”, Cuadernos de Pedagogía, 296. zb., 56-59 or.

MARTOS, J.; eta BURGOS, M. A. (2013): "Del autismo infantil precoz al trastorno de espectro autista", in ALCANTUD MARÍN, F. (koord.), Trastornos del espectro autista: detección, diagnóstico e intervención temprana, Madril, Pirámide, 17-33 or.
MEYER, R. N. (2001): Asperger Syndrome Employment Workbook: An Employment Workbook for Adults with Asperger Syndrome, Londres, Jessica Kingsley Publishers.

MURILLO, E. (2012): “Actualización conceptual de los trastornos del espectro del autismo (TEA)", in MARTÍNEZ MARTÍN, M. A.; eta CUESTA GÓMEZ, J. L. (koord.), Todo sobre el autismo: Los trastornos del espectro del autismo (TEA). Guía completa basada en la ciencia y en la experiencia, Tarragona, Altaria, 23-63 or.

OSASUN, GIZARTE ZERBITZU ETA BERDINTASUN MINISTERIOA (2015a): "Empleo y discapacidad" [<http://www.msssi.gob.es/ssi/discapacidad/ informacion/empleoDiscapacidad.htm〉].

- (2015b): “Más información” [<http://www.msssi. gob.es/ssi/discapacidad/informacion/ empMasInformacion.htm〉].

RIVIÈRE, A. (2001): Autismo: orientaciones para la intervención educativa, Madrid, Trotta.

RODRÍGUEZ GÓMEZ, D.; eta VALLDEORIOLA, J. (2009): Metodología de la investigación, Barcelona, Eureca Media.

RUSSELL, J. (1997): “How executive disorders can bring about an adequate theory of mind", in RUSSELL, J. (ed.), Autism as an Executive Disorder, Oxford, Oxford University Press, 256 304 or.

SALDAÑA, D. et al. (2006): Vida adulta y trastornos del espectro autista: calidad de vida y empleo en Andalucía, Sevilla, Autismo Andalucía.

SÁNCHEZ-CERVERA, J. M. (2005): "Los enclaves laborales”, Siglo Cero, 214. zb., 30-40 or.

TAYLOR, S. J.; eta BOGDAN, R. (1987): Introducción a los métodos cualitativos de investigación: la búsqueda de significados, Barcelona, Paidós Ibérica.

WEHMAN, P. et al. (1987): Transition from School to Work. New Challenges for Youth with Severe Disabilities, Baltimore, Paul H. Brookes.

VERDUGO, M. A.; eta JENARO, C. (1993): “Una nueva posibilidad laboral para personas con discapacidad: el empleo con apoyo", Siglo Cero, 147. zb., 5-12 or.

VERDUGO, M. A.; eta JORDÁN DE URRÍES, F. B. (2007): “El futuro del empleo con apoyo. ¿Hacia dónde nos dirigimos?", Zerbitzuan, 41. zb., 145-152 or. [<http://www.zerbitzuan.net/documentos/ zerbitzuan/El\%2ofuturo\%2odel\%20 empleo\%2ocon\%2oapoyo.pdf〉].

VERDUGO, M. A.; JORDÁN DE URRÍES, F. B.; eta BELLVER, F. (1998): "Situación actual del empleo con apoyo en España”, Siglo Cero, 29. zb., 23-31 or.

VERDUGO, M. A., et al. (2010): "La mejora de la calidad de vida mediante el empleo con apoyo. La experiencia del programa ECA Caja Madrid", Educación y Futuro. Revista de Investigación Aplicada y Experiencias Educativas, 23. zb., 13-30 or.

WING, L. (1997): "The history of ideas on autism: legends, myths and reality", Autism, 1. zb., 13-23 or.

- (1988): Aspects of Autism: Biological Research, Londres, Gaskell. 